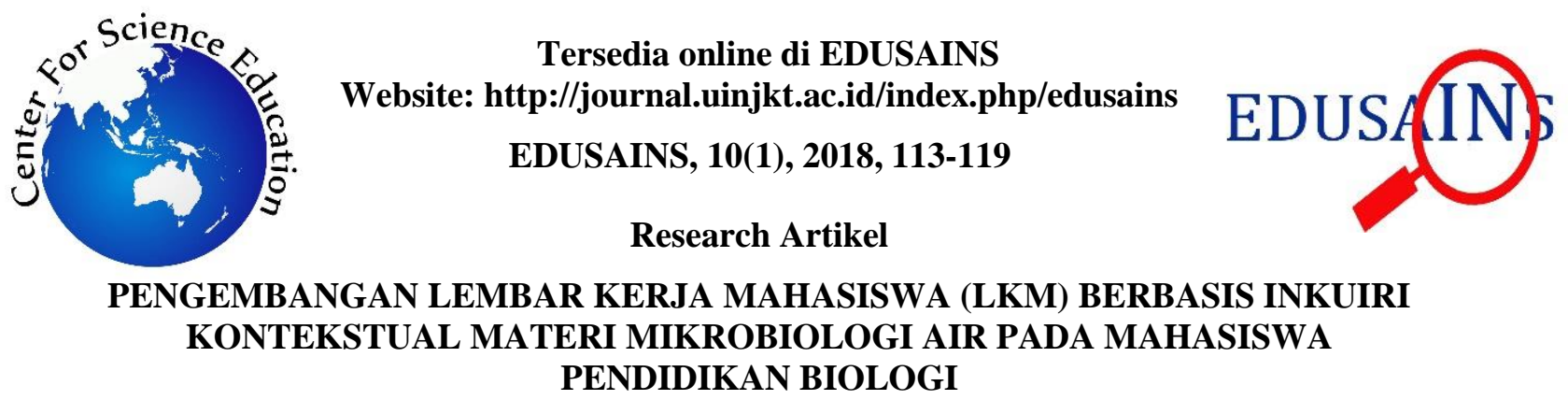

\title{
THE DEVELOPMENT OF STUDENT WORKSHEET BASED CONTEXTUAL INQUIRY OF AQUATIC MICROBIOLOGY MATERIAL IN STUDENTS DEPARTMENT OF BIOLOGY EDUCATION
}

\author{
Yusnita Anwar Nasution, Hasruddin, Tumiur Gultom \\ Pendidikan Biologi PPs, Universitas Negeri Medan, Indonesia \\ yusnitaanwarnasution@gmail.com
}

\begin{abstract}
The study aims to determine: (1) The results expert material validation of worksheet that has been developed; (2) The results of design experts validation of worksheet that has been developed; (3) Response of lecturer of microbiology subject to worksheet that has been developed; (4) Perception of University of Medan Biology Education students to Worksheet that has been developed; (5) The eligibility of Worksheet for Biology Education students of State University of Medan. This development study uses a modified Borg \& Gall model as needed to produce a product of a contextual inquiry-based worksheet. The results of material expert validation to microfinance based worksheet in context of water microbiology materials that have been developed with the feasibility of the contents show $93.75 \%$ included in the category of very good; Feasibility of presentation shows $91.44 \%$ included in the category of very good; The feasibility of the contextual inquiry component indicates $87.82 \%$ in the category of good good; The design validation results show that $89.06 \%$ percentage is included in the category of very good; The result of the assessment by the lecturer shows $93.75 \%$ is included in the category of very good; Individual tests show 86,66\% included in the category of very good; Small group test showed $87.22 \%$ included in the category of very good; The test of the restricted group shows $91.12 \%$ included in the the category of very good. Test based on the data the product worksheet based on inquiry of contextual material of water microbiology which have been developed feasible to be used for student as worksheet in Microbiology course.
\end{abstract}

Keywords: development of student worksheet; aquatic microbiology; contextual; inquiry

\section{Abstrak}

Penelitian ini bertujuan untuk mengetahui: (1) Hasil validasi ahli bahan lembar kerja yang telah dikembangkan; (2) Hasil validasi ahli desain lembar kerja yang telah dikembangkan; (3) Tanggapan dosen mata kuliah mikrobiologi terhadap lembar kerja yang telah dikembangkan; (4) Persepsi mahasiswa Pendidikan Biologi Universitas Medan terhadap Lembar Kerja yang telah dikembangkan; (5) Kelayakan Lembar Kerja untuk mahasiswa Pendidikan Biologi Universitas Negeri Medan. Studi pengembangan ini menggunakan model Borg \& Gall yang dimodifikasi sesuai kebutuhan untuk menghasilkan produk dari lembar kerja berbasis inkuiri kontekstual. Hasil validasi ahli materi terhadap LKM berbasis microfinance dalam konteks bahan mikrobiologi air yang telah dikembangkan dengan kelayakan isinya menunjukkan 93,75\% termasuk dalam kategori sangat baik; Kelayakan presentasi menunjukkan $91,44 \%$ termasuk dalam kategori sangat baik; Kelayakan komponen penyelidikan kontekstual menunjukkan $87,82 \%$ dalam kategori barang bagus; Hasil validasi desain menunjukkan bahwa 89,06\% termasuk dalam kategori sangat baik; Hasil penilaian oleh dosen menunjukkan 93,75\% termasuk dalam kategori sangat baik; Tes individu menunjukkan 86,66\% termasuk dalam kategori sangat baik; Uji kelompok kecil menunjukkan 87,22\% termasuk dalam kategori sangat baik; Tes kelompok terbatas menunjukkan $91,12 \%$ termasuk dalam kategori sangat baik. Uji berdasarkan data lembar kerja produk berdasarkan permintaan bahan kontekstual mikrobiologi air yang telah dikembangkan layak untuk digunakan untuk siswa sebagai lembar kerja di Mikrobiologi saja.

Kata Kunci: pengembangan lembar kerja siswa; mikrobiologi air; kontekstual; inkuiri

Permalink/DOI: http://dx.doi.org/10.15408/es.v10i1.8124 


\section{PENDAHULUAN}

Pada Prodi Pendidkan Biologi semester IV FMIPA Universitas Negeri Medan (UNIMED), terdapat matakuliah mikrobiologi yang salah satu materinya yaitu mikrobiologi air. Air selain bermanfaat bagi manusia, juga merupakan media yang baik untuk kehidupan bakteri. Air yang aman untuk diminum adalah air bersih yang harus memenuhi persyaratan secara fisika, kimia, radioaktif dan mikrobiologi yang telah ditetapkan oleh pemerintah. Secara mikrobiologi, salah satu syarat air bersih yang dapat dikonsumsi adalah tidak ditemukannya Escherichia coli. Escherichia coli termasuk bakteri yang dapat menyebabkan keluhan diare. Untuk mengetahui ada tidaknya bakteri yang terdapat di dalam air maka diperlukan pembelajaran melalui praktikum.

Tuntutan kurikulum mensyaratkan pembelajaran memenuhi keselarasan ketiga ranah (kognitif, afektif, dan psikomotor) di dalam mengembangkan produk, proses, sikap dan pembekalan pembelajaran sains. Ini semua dapat diwujudkan dengan kegiatan pembelajaran yang dibekali dengan perangkat lembar kerja mahasiswa (LKM). Dalam hal ini kegiatan pembelajaran diperlukan adanya satu panduan yang terarah yaitu lembar kerja mahasiswa (LKM) (Depdiknas, 2008).

Melalui sebaran angket (analisis kebutuhan) yang diperoleh dari mahasiswa Pendidikan Biologi FMIPA UNIMED yang telah mengikuti mata kuliah mikrobiologi, hasil dari angket yang dilakukan secara random terlihat bahwa mahasiswa membutuhkan Lembar Kerja Mahasiswa (LKM) berbasis inkuri kontekstual pada materi mikrobiologi air. Karena kegiatan praktikum pada materi tersebut belum menggunakan Lembar Kerja Mahasiswa (LKM) yang melibatkan aspek-aspek yang mengadung inkuiri kontekstual.

\begin{tabular}{llrr}
\multicolumn{1}{c}{ Prinsip } & yang & melandasi & penelitan \\
pengembangan & adalah: & $(1)$ & penelitian \\
pengembangan & beriplikasi & pada & model dan \\
perangkat untuk & mengatasi masalah pembelajaran;
\end{tabular}
(2) Perangkat pembelajaran merupakan bagian integral dari pembelajaran dimana pengembangan sesuai dengan permasalahan yang dihadapi di kelas atau di laboratorium dan pengembangan melalui prosedur pengembangan produk; (3) Teknik dan prosedur pengembangan produk dilakukan melalui tahap dan kaidah ilmiah, alternatif pemecahan masalah, perancangan dan pelaksanaan validitas pakar serta revisi produk (Rahmat, 2007).

Penelitian pendidikan dan pengembangan atau Educational Research and Development $(\mathrm{R} \&$ D) adalah proses yang digunakan untuk menngembangkan dan memvalidasi produk pendidikan. Langkah-langkah proses ini biasanya disebut sebagai siklus $\mathrm{R} \& \mathrm{D}$ yang mempelajari temuan penelitian yang berkaitan dengan produk yang akan dikembangkan, mengembangkan produk berdasarkan temuan. Pengaturan dalam bidang pengujian dimana akhirnya akan digunakan dan merevisi untuk memperbaiki kekurangan yang ditemukan dalam tahap mengajukan pengujian.

Menurut Rahmat (2007) penelitian pengembangan harus mendukung pemecahan masalah praktis dalam pendidikan khususnya masalah pembelajaran di kelas atau di laboratorium. Penelitian pengembangan menjembatani kesenjangan antara penelitian dengan implementasi hasil penelitian dalam bentuk pembelajaran di kelas atau di laboratorium. Jadi sebelum proses pengembangan dimulai perlu dilakukan terlebih dahulu pencermatan dan seleksi terhadap produk yang akan dikembangkan, diantaranya produk yang dihasilkan harus relevan untuk memenuhi kebutuhan permasalahan pembelajaran.

LKM merupakan bahan ajar cetak berupa lembaran-lembaran yang disusun secara sistematis berisi materi, ringkasan dan petunjuk pelaksanaan pembelajaran bertujuan agar dapat menentukan mahasiswa melakukan kegiatan yang aktif mengacu pada kompetisi dasar (Prastowo (2011). Lembar Kerja Mahasiswa (LKM) yang identik dengan Lembar Kerja Siswa (LKS) jika digunakan di sekolah adalah salah satu bentuk program yang berdasarkan atas tugas dan fungsi sebagai alat untuk mengalihkan pengetahuan dan keterampilan. LKS/LKM memiliki peran yang sangat besar dalam proses pembelajaran, karena LKS/LKM dapat membantu pendidik untuk mengarahkan peserta didiknya menemukan konsep-konsep melalui aktivitasnya (Depdiknas, 2008).

Adapun manfaat penggunaan LKM bagi kegiatan pembelajaran menurut adalah: (1) 
Mengaktifkan mahasiswa dalam proses pembalajaran; (2) Membantu mahasiswa dalam mengembangkan konsep; (3) Melatih mahasiswa dalam menemukan dan menengembangkan keterampilan proses; (4) Melatih mahasiswa untuk memecahkan masalah dan berpikir kritis; (5) Sebagai pedoman mahasiswa dalam melaksanakan proses pembelajaran; (6) Membantu mahasiswa memperoleh catatan tentang materi yang dipelajari melalui kegiatan belajar; dan (7) Membantu mahasiswa menambah informasi tentang konsep yang dipelajari kegiatan belajar secara sistematis (Widjajanti, 2008).

Inkuiri adalah rangkaian kegiatan pembelajaran yang menekankan pada proses berpikir secara kritis dan analitis untuk mencari dan menemukan sendiri jawaban dari suatu masalah yang dipertanyakan. Inkuiri ini merupakan bagian dari pembelajaran kontekstual. Inkuiri (menemukan) merupakan komponen ketiga dari komponen utama dalam pembelajaran kontekstual. Langkah-langkah proses pembelajaran dengan menggunakan pendekatan inkuiri kontekstual yiaitu orientasi, merumuskan masalah, merumuskan hipotesis, mengumpulkan data, menguji hipotesis, merumuskan kesimpulan (Sanjaya, 2009).

\section{METODE}

Penelitian Ini dilaksanakan di Laboratorium Biologi FMIPA Universitas Negeri Medan yang terletak di Jalan William Iskandar Pasar V - Kode Pos 20221. Penelitian dilaksanakan pada bulan April-Juni 2017.

Subjek uji coba terdiri dari tim ahli materi, tim ahli desain, 3 mahasiswa Prodi Pendidikan Biologi uji perorangan, 9 mahasiswa Prodi Pendidikan Biologi uji kelompok kecil, 20 mahasiswa Prodi Pendidikan Biologi uji kelompok terbatas.

Jenis penelitian ini adalah penelitian dan pengembangan (Research and Development). Penelitian pengembangan dengan produk yang dikembangkan adalah berupa LKM berbasis inkuiri kontekstual materi mikrobiologi air yang pengembangannya mengacu pada penelitian pengembangan model Borg \& Gall. Penelitian pengembangan ini dilakukan berdasarkan hasil analisis kebutuhan dan analisis masalah.

Prosedur penelitian yang dilakukan dalam penelitian pengembangan LKM berbasis inkuiri kontekstual pada materi Mikrobiologi Air dibagi menjadi beberapa tahap, yaitu: (1) Tahap I: Analisis kebutuhan, tahap ini bertujuan untuk mengumpulkan informasi yang relevan untuk pengembangan LKM berbasis inkuiri kontekstual dengan cara wawancara dosen pengampu mata kuliah dan menyebarkan angket analisis kebutuhan kepada mahasiswa; (2) Tahap II: Desain produk LKM, tahapan ini bertujuan untuk merencanakan desain LKM. Setiap LKM dirancang sesuai standar inkuiri kontekstual dan untuk menghasilkan produk awal sebelum diteskan kepada mahasiswa berupa LKM berbasis inkuiri kontekstual; (3) Tahap III: Pembuatan produk awal LKM yang berisis inkuiri kontekstual. Validasi ahli materi yang divalidkan oleh ahli materi mikrobiologi, validasi desain divalidkan oleh ahli desain. Tahapan ini bertujuan untuk mengetahui kelayakan produk yang dikembangkan dalam LKM berbasis inkuiri kontekstual; (4) Tahap IV: Revisi pertama; (5) Tahap V: Penilaian dosen mikrobiologi; (6) Tahap VI: Revisi terhadap produk apabila membutuhkan revisi; (7) Tahap VII: Uji kelompok kecil; (8) Tahap VIII: Revisi terhadap produk dari hasil uji coba apabila membutuhkan revisi; (9) Tahap IX: Uji kelompok terbatas.; (10) Tahap X: Revisi terhadap produk dari hasil uji coba apabila membutuhkan revis; (11) Tahap XI: Revisi akhir dari uji coba apabila membutuhkan revisi; dan (12) Tahap XII: Hasil akhir, merupakan produk LKM yang telah valid dan direvisi sesuai dengan masukan serta saran-saran, sehingga terbentuklah LKM berbasis inkuiri kontekstual.

\section{HASIL DAN PEMBAHASAN Hasil}

Tahapan pengembangan lembar kerja mahasiswa (LKM) berbasis inkuiri kontekstual materi mikrobiologi air. Tahap pertama yaitu melakukan analisis masalah dan kebutuhan untuk mengumpulkan informasi berupa kajian pustaka, validasi oleh tim ahli materi, desain dan uji kelompok terbatas serta analisis terhadap LKM yang digunakan oleh mahasiswa pendidikan biologi di Universitas Negeri Medan. Setelah itu penulis melakukan perencanaan LKM berbasis inkuiri kontekstual materi mikrobiologi air yang 
dikembangkan berdasarkan komponen inkuiri kontekstual.

Tabel 1. Data Analisis Awal Komponen Inkuiri Kontekstual Pada LKM Materi Mikrobiologi Air

\begin{tabular}{|c|c|c|}
\hline $\begin{array}{c}\text { Sub Komponen } \\
\text { Penelitian } \\
\end{array}$ & $\begin{array}{c}\text { Rata-rata } \\
(\%)\end{array}$ & Kriteria \\
\hline $\begin{array}{c}\text { Inkuiri } \\
\text { Orientasi }\end{array}$ & 52,08 & $\begin{array}{c}\text { Sangat } \\
\text { Kurang } \\
\text { Baik }\end{array}$ \\
\hline Merumuskan masalah & 50,00 & $\begin{array}{c}\text { Sangat } \\
\text { Kurang } \\
\text { Baik } \\
\text { Sangat }\end{array}$ \\
\hline Merumuskan hipotesis & 50,00 & $\begin{array}{c}\text { Kurang } \\
\text { Baik }\end{array}$ \\
\hline Mengumpulkan data & 67,85 & $\begin{array}{l}\text { Kurang } \\
\text { Baik } \\
\text { Sangat }\end{array}$ \\
\hline Menguji hipotesis & 50,00 & $\begin{array}{c}\text { Kurang } \\
\text { Baik }\end{array}$ \\
\hline Membuat kesimpulan & 63,88 & $\begin{array}{l}\text { Kurang } \\
\text { Baik } \\
\text { Sangat }\end{array}$ \\
\hline Kontekstual & 54,16 & $\begin{array}{c}\text { Kurang } \\
\text { Baik }\end{array}$ \\
\hline
\end{tabular}

Berdasarkan data tabel diatas diketahui bahwa persentase tujuh komponen inkuiri kontekstual pada LKM yang digunakan lebih cenderung yag tampak yaitu pada sub komponen mengumpulkan data dan membuat kesimpulan dengan rata-rata dengan kriteria nilai kurang baik, akan tetapi untuk sub komponen orientasi, merumuskan masalah, merumuskan hipotesis, menguji hipoteesis, dan kontekastual sangat kurang baik.

Tabel 2. Penilaian Tim Ahli Materi Lembar Kerja

Mahasiswa Berbasis Inkuiri Kontekstual untuk Kelayakan Isi

\begin{tabular}{cccc}
\hline $\begin{array}{c}\text { Sub } \\
\text { Indikator }\end{array}$ & $\begin{array}{c}\text { Jlh } \\
\text { skor }\end{array}$ & $\begin{array}{c}\text { Rata-rata } \\
(\mathbf{\%})\end{array}$ & Kritera \\
\hline $\begin{array}{c}\text { Kesesuaian } \\
\text { Konsep }\end{array}$ & 21 & 87,50 & Sangat baik \\
$\begin{array}{c}\text { Keakuratan } \\
\text { Materi }\end{array}$ & 92 & 95,83 & Sangat baik \\
$\begin{array}{c}\text { Materi } \\
\text { Pendukung }\end{array}$ & 22 & 91,60 & Sangat baik \\
$\begin{array}{c}\text { Perkuliahan } \\
\text { Jumlah Skor } \\
\text { Total dan } \\
\text { Rata-rata }\end{array}$ & 135 & $\mathbf{9 3 , 7 5}$ & Sangat baik \\
\hline
\end{tabular}

Penilaian tentang kelayakan isi menurut tim ahli materi dinilai "sangat baik/sangat layak" dengan total persentase rata-rata sebasar $93,75 \%$. Data hasil validasi tim ahli materi terhadap kelayakan penyajian dapat dilihat pada Tabel 3.
Tabel 3. Penilaian Tim Ahli Materi LKM Berbasis Inkuiri Kontekstual untuk Kelayakam Penyajian

\begin{tabular}{cccc}
\hline $\begin{array}{c}\text { Sub } \\
\text { Indikator }\end{array}$ & $\begin{array}{c}\text { Jlh } \\
\text { Skor }\end{array}$ & $\begin{array}{c}\text { Rata-rata } \\
(\%)\end{array}$ & Kritera \\
\hline $\begin{array}{c}\text { Teknik } \\
\text { Penyajian }\end{array}$ & 53 & 94,66 & Sangat baik \\
$\begin{array}{c}\text { Kejelasan } \\
\text { Kalimat }\end{array}$ & 58 & 90,62 & Sangat baik \\
$\begin{array}{c}\text { Kebahasaan } \\
\text { Kelengkapan } \\
\text { Penyajian }\end{array}$ & 28 & 87,50 & Sangat baik \\
$\begin{array}{c}\text { Jumlah Skor } \\
\text { Total dan } \\
\text { Rata-rata }\end{array}$ & 139 & 91,44 & Sangat baik \\
\hline
\end{tabular}

Penilaian kelayakan penyajian menurut tim ahli materi dinilai "sangat baik/sangat layak" dengan total persentase rata-rata $91,44 \%$. Data hasil validasi tim ahli materi terhadap komponen inkuiri kontekstual dapat dilihat pada Tabel 4.

Tabel 4. Penilaian Tim Materi LKM Berbasis Inkuiri Kontekstual Untuk Komponen Kontekstual

\begin{tabular}{|c|c|c|c|}
\hline $\begin{array}{c}\text { Sub } \\
\text { Indikator }\end{array}$ & $\begin{array}{c}\text { Jlh } \\
\text { skor }\end{array}$ & $\begin{array}{c}\text { Rata-rata } \\
(\%)\end{array}$ & Kritera \\
\hline $\begin{array}{c}\text { Inkuiri } \\
\text { Orientasi }\end{array}$ & 29 & 90,62 & Sangat baik \\
\hline $\begin{array}{l}\text { Merumuskan } \\
\text { masalah }\end{array}$ & 49 & 87,50 & Sangat baik \\
\hline $\begin{array}{l}\text { Merumuskan } \\
\text { hipotesis }\end{array}$ & 42 & 87,50 & Sangat baik \\
\hline $\begin{array}{l}\text { Mengumpulka } \\
\text { n data }\end{array}$ & 49 & 87,50 & Sangat baik \\
\hline $\begin{array}{l}\text { Menguji } \\
\text { hipotesis }\end{array}$ & 35 & 87,50 & Sangat baik \\
\hline $\begin{array}{l}\text { Membuat } \\
\text { kesimpulan }\end{array}$ & 7 & 87,50 & Sangat baik \\
\hline Kontekstual & 56 & 87,50 & Sangat baik \\
\hline $\begin{array}{c}\text { Jumlah Skor } \\
\text { Total dan } \\
\text { Rata-rata }\end{array}$ & 267 & 87,82 & Sangat baik \\
\hline
\end{tabular}

Penilaian tentang kelayakan konponen inkuiri kontekstual menurut tim ahli materi dinilai "sangat baik/sangat layak" dengan total persentase rata-rata sebesar $87,82 \%$. Data hasil validasi tim ahli ahli desain LKM berbasis Inkuiri Kontekstual untuk desain grafis yang meliputi perwajahan, desain isi dan ilustrasi isi LKM.

Tabel 5. Penilaian Tim Ahli Desain LKM Berbasis Inkuiri Kontekstual untuk Desain Grafis yang meliputi Perwajahan, Desain Isi dan Ilustrasi Isi LKM

\begin{tabular}{cccc}
\hline Sub Indikator & $\begin{array}{c}\text { Jlh } \\
\text { skor }\end{array}$ & $\begin{array}{c}\text { Rata- } \\
\text { rata } \\
(\boldsymbol{\%})\end{array}$ & Kritera \\
\hline Perwajahan & 64 & 88,88 & Sangat baik \\
Desain I & 81 & 92,04 & Sangat baik \\
Ilustrasi Isi & 26 & 81,25 & Baik \\
$\begin{array}{c}\text { Jumlah Skor } \\
\text { Total dan Rata- }\end{array}$ & 171 & 89.06 & Sangat baik \\
$\quad$ rata & & & \\
\hline
\end{tabular}


Penilaian tentang desain grafis LKM menurut tim ahli desain diniai "sangat baik/sangat layak" dengan total persentase rata-rata sekitar $89,06 \%$. Tabel peilaian oleh dosen mikrobiologi dapat dilihat pada Tabel 6 .

Tabel 6. Penilaian Oleh Dosen Mikrobiologi

\begin{tabular}{cccc}
\hline $\begin{array}{c}\text { Sub } \\
\text { Indikator }\end{array}$ & $\begin{array}{c}\text { Jlh } \\
\text { skor }\end{array}$ & $\begin{array}{c}\text { Rata-rata } \\
(\boldsymbol{\%})\end{array}$ & Kritera \\
\hline $\begin{array}{c}\text { Keseluruhan } \\
\text { Tampilan }\end{array}$ & & & \\
sampai & 75 & 93,75 & Sangat baik \\
dengan Isi & & & \\
LKM & & & \\
\hline
\end{tabular}

Penilaian yang diberikan oleh dosen dinilai "sangat baik/sangat layak" dengan persentase ratarata $93,75 \%$. Data hasil uji perorangan dapat dilihat pada Tabel 7.

Tabel 7. Data Respon Mahasiswa Dari Uji Coba Perorangan (3 Mahasiswa) Terhadap LKM

\begin{tabular}{cccc}
\hline $\begin{array}{c}\text { Sub } \\
\text { Indikator }\end{array}$ & $\begin{array}{c}\text { Jlh } \\
\text { skor }\end{array}$ & $\begin{array}{c}\text { Rata-rata } \\
(\boldsymbol{\%})\end{array}$ & Kritera \\
\hline $\begin{array}{c}\text { Tampilan } \\
\text { Fisik sampai } \\
\text { Ukuran dan }\end{array}$ & 104 & 86,66 & Sangat baik \\
jenis huruf & & & \\
\hline
\end{tabular}

Data hasil respon mahasiswa uji coba perorangan dapat disimpulkan bahwa LKM termasuk kedalam kategori "sangat baik" dengan persentase skor rata-rata 86,66\%. Data hasil respon mahasiswa uji coba kelompok kecil disajikan pada Tabel 8.

Tabel 8. Data Respon Mahasiswa dari Uji Coba Kelompok Kecil (9 Mahasiswa) tehadap LKM

\begin{tabular}{cccc}
\hline $\begin{array}{c}\text { Sub } \\
\text { Indikator }\end{array}$ & $\begin{array}{c}\text { Jlh } \\
\text { skor }\end{array}$ & $\begin{array}{c}\text { Rata-rata } \\
(\mathbf{\%})\end{array}$ & Kritera \\
\hline $\begin{array}{c}\text { Tampilan } \\
\text { Fisik sampai }\end{array}$ & 314 & 87,22 & Sangat baik \\
$\begin{array}{c}\text { Ukuran dan } \\
\text { jenis huruf }\end{array}$ & & & \\
\hline
\end{tabular}

Data hasil respon mahasiswa uji coba kelompok kecil dapat disimpulkan bahwa LKM termasuk kedalam kategori "sangat baik" dengan rata-rata $87,2 \%$. Data hasil respon mahasiswa uji coba kelompok terbatas disajikan pada Tabel 9.

Tabel 9. Data Respon Mahasiswa dari Uji Coba Terbatas (20 Mahasiswa) terhadap LKM

\begin{tabular}{cccc}
\hline $\begin{array}{c}\text { Sub } \\
\text { Indikator }\end{array}$ & $\begin{array}{c}\text { Jlh } \\
\text { sko } \\
\mathbf{r}\end{array}$ & $\begin{array}{c}\text { Rata-rata } \\
(\boldsymbol{\%})\end{array}$ & Kritera \\
\hline $\begin{array}{c}\text { Tampilan Fisik } \\
\text { sampai Ukuran } \\
\text { dan jenis huruf }\end{array}$ & 729 & 91,12 & Sangat baik \\
\hline
\end{tabular}

Data hasil respon mahasiswa uji coba terbatas dapat disimpulkan bahwa LKM termasuk kedalam kategori "sangat baik" dengan rata-rata $91,12 \%$.

Keseluruhan dari persentase mahasiswa terhadap engembangan LKM berbasis inkuiri kontekstual materi mikrobiologi air dapat dilihat pada Tabel 10.

Tabel 10. Persentase Persepsi Mahasiswa terhadap

Pengembangan LKM berbasis Inkuiri Kontekstual Materi Mikrobiologi Air

\begin{tabular}{ccc}
\hline $\begin{array}{c}\text { Sub Komponen } \\
\text { Penilaian }\end{array}$ & $\begin{array}{c}\text { Rata-rata } \\
(\boldsymbol{\%})\end{array}$ & Kriteria \\
\hline $\begin{array}{c}\text { Uji coba perorangan }(3 \\
\text { mahasiswa) }\end{array}$ & 86,66 & $\begin{array}{c}\text { Sangat } \\
\text { Baik }\end{array}$ \\
$\begin{array}{c}\text { Uji coba kelompok kecil }(9 \\
\text { mahasiswa) }\end{array}$ & 87,22 & $\begin{array}{c}\text { Sangat } \\
\text { Baik }\end{array}$ \\
$\begin{array}{c}\text { Uji coba kelompok terbatas } \\
\text { (20 mahaiswa) }\end{array}$ & 91,12 & $\begin{array}{c}\text { Sangat } \\
\text { Baik }\end{array}$ \\
\hline
\end{tabular}

Data hasil respon mahasiswa uji coba termasuk dalam kategori sangat baik.

\section{Pembahasan}

Produk akhir dari pengembangan yang dilakukan adalah LKM berbasis inkuiri kontekstual materi mikrobiolgi air. LKM yang dikembangkan dirancang dengan memuat komponen-komponen inkuiri. Hal ini sesuai dengan Sanjaya (2009) bahwa proses permbelajaran berbasis inkuiri meliputi orientasi, merumuskan masalah, merumuskan hipotesis, mengumpulkan data, menguji hipotesis, menarik kesimpulan.

Hasil validasi dari ahli materi terhadap kelayakan isi dari LKM yang dikembangkan menunjukkan bahwa; (1) Kesesuaian konsep dinilai sangat baik dengan persentase $87,5 \%$; (2) Keakuratan materi dinilai sangat baik dengan persentase 95,8\%; dan (3) Materi pendukung pembelajaran dinilai sangat baik dengan persentase 91,6\%. Dengan demikian LKM berbasis inkuiri kontekstual materi mikrobiologi air yang dikembangkan berdasarkan kelayakan isi secara keseluruhan termasuk dalam kategori "sangat baik".

Hasil validasi dari ahli materi terhadap kelayakan penyajian dari LKM yang dikembangkan menunjukkan bahwa; (1) Teknik penyajian dinilai sangat baik dengan persentase $94,44 \%$; (2) Kejelasan kalimat kebahasaan dinilai sangat baik dengan persentase $90,62 \%$; (3) Kelengkapan 
penyajian dinilai sangat baik sengan persentase 87,5\%. Dengan demikian LKM berbasis inkuiri kontekstual materi mikrobiologi air yang dikembangkan berdasarkan kelayakan penyajian secara keseluruhan termasuk dalam kategori "sangat baik". Menurut Abdi (2014) pembelajaran inkuiri akan membangun kemampuan dan aktifitas mahasiswa menjadi lebih baik.

Hasil validasi dari ahli materi terhadap komponen inkuiri kontekstual dari LKM yang dikembangkan menunjukkan bahwa; (1) Orientasi dinilai sangat baik dengan persentase $90,62 \%$; dan (2) rumusan masalah sampai dengan kesimpulan dan kontekstual dinilai sangat baik dengan persentase 87,5\%; Dengan demikian LKM berbasis inkuiri kontekstual materi mikrobiologi air yang dikembangkan berdasarkan komponen inkuiri kontekstual secara keseluruhan termasuk dalam kategori "sangat baik". Menurut Bednar (2007) kepada peserta didik untuk meningkatkan keprcayaan diri dari proses memecahkan masalah.

Menurut hasil penelitian Andrini (2016) bahwa inkuiri membantu mahasiswa untuk memecahkan masalah melalui kegiatan penyelidikan yang meningkatkan keterampilan dan pengetahuan secara mandiri, dengan adanya inkuri memberikan kesempatan bagi mahasiswa untuk membangun pengetahuan merka sendiri, menggunakan konsep yang telah diselenggarakan untuk memecahkan masalah yang dihadapi dan mahasiswa memiliki kesempatan untuk menghubungkan informasi baru dengan struktur kognitif, psikomotor dan kemampuan efektif mahasiswa juga dapat dikembangkan.

Hasil validasi dari ahli desain pembelajaran teradap kelayakan penyajian dari LKM yamg dikembangkan menunjukkan bahwa; (1) Perwajahan LKM dinilai sangat baik dengan persentase 88,88\%; (2) Desain isi LKM dinilai sangat baik dengan persentase $92,04 \%$; dan (3) Ilustrasi isi dinilai baik dengan persentase $81,25 \%$. Dengan demikian LKM berbasis inkuiri kontekstual materi mikrobiologi air yang dikembangkan berdasarkan kelayakan desain LKM secara keseluruhan termasuk dalam kategori sangat baik.

Berdasarkan data hasil respon mahasiswa Pendidikan Biologi Universitas Negeri Medan pada uji coba perorangan diyatakan bahwa LKM yang dikembangkan termasuk dalam ketegori sangat baik dengan persentase $86,66 \%$. Setelah dilakukan revisi dari kekurangan yang terdapat pada uji coba perorangan, maka selanjutnya dilakkukan uji coba kelompok kecil. Dari data hasil respon mahasiswa pada uji kelompok kecil menunjukkan bahwa LKM yang dikembangkan termasuk dalam kategori sangat baik dengan persentase $87,22 \%$. Selanjutnya dilakukan uji kelompok terbatas, dari data hasil respon mahasiswa yang diperoleh pada uji cobal kelompok terbatas ini menunjukkan bahwa LKM yang dikembangkan termasuk dalam kategoro sangat baik dengan persentase $91,12 \%$.

Uji coba produk dilakukan pada pengembangan LKM berbasis inkuiri kontekstual materi mikrobiologi air ini bertujuan untuk memgetahui apakah produk yangdibuat layak digunakan atau tidak. Uji produk ini juga melihat sejauh mana produk yag dibuat dapat mencapai sasaran dan tujuan. Dengan demikian LKM yang dikembangkan berdasarkan kelayakan isi dan kelayakan penyajian secara keseluruhan termasuk kategori "sangat baik". Dalam penilaian LKM ini, penilaian ditentukan dengan nilai minimal persentase $75 \%-84 \%$, yaitu dengan kategori baik. Jadi jika rata-rata penilaian oleh tim ahli materi dan desain, serta hasil uji coba kepada dosen mikrobiologi dan uji pada mahasiswa menunjukkan persentase $75 \%-84 \%$, maka pengembangan LKM ini dikategorikan layak digunakan dalam proses pembelajaran mikrobiologi.

\section{PENUTUP}

Berdasarkan hasil penelitian maka dpat disimpulkan bahwa: (1) Hasil validasi ahli materi terhadap LKM yang dikembangkan secara keseluruhan termasuk dalam kategori sangat baik; (2) Hasil validasi ahli desain terhadap LKM yang dikembangkan secara keseluruhan termasuk dalam kategori sangat baik; (3) Menurut tanggapan dosen mata kuliah mikrobiologi terhadap LKM yang dikembangkan secara keseluruhan termasuk dalam kategori sangat baik.; dan (4) Menurut tanggapan mahasiswa pendidikan biologi Universitas Negeri Medan terhadap LKM yang dikembangkan secara keseluruhan termasuk dalam kategori sangat baik. 
Dengan demikian LKM yang dikembangkan berdasarkan kelayakan isi dan kelayakan penyajian secara keseluruhan termasuk kategori "sangat baik". Dalam penilaian LKM ini, penilaian ditentukan dengan nilai minimal persentase $75 \%$ $84 \%$, yaitu dengan kategori baik. Jadi jikarata-rata penilaian oleh tim ahli materi dan desain, serta hasil uji coba kepada dosen mikrobiologi dan uji pada mahasiswa menunuukkan persentase 75\%-84\%, maka pengembangan LKM ini dikategorikan layak digunakan dalam proses pembelajaran Mikrobiologi.

Berdasarkan pada proses pengembangan yang telah dilakuakan, hasil uji coba dan kesimpulan yang telah dipaparkan, diperlukan saran-saran untuk pengembangan lebih lanjut. Adapun saran-saran yang diajukan sebagai barikut: (1) LKM ini disusun dengan pembelajaran inkuiri kontekstual. Oleh karena itu LKM dapat digunakan sebagai pedoman praktikum tambahan sehingga mampu member umpan balik yang lebih baik bagi mahasiswa; (2) Untuk pemahaman yang lebih mendalam dan kesempurnaan LKM, perlu dikembangkan LKM berbasis inkuiri kontekstual materi mikrobiologi air yang cakupannya lebih luas lagi agar mendapat hasil yang lebih maksimal; dan (3) Hasil penelitian yang penulis lakukan pada penelitian pengembangan ini masih memungkinkan dipengaruhi oleh faktor-faktor yang belum mampu terkendali, maka masih perlu kiranya dilakukan penelitian lebih lanjut pada materi dan sampel yang lebih banyak agar hasil yang di dapat lebih maksimal.

\section{UCAPAN TERIMAKASIH}

Diucapkan kepada Direktorat Riset dan Pengabdian pada Masyarakat, Direktorat Jenderal Penguatan Riset dan Pengembangan Kementrian Riset, Teknologi, dan Pendidikan Tinggi, sesuai dengan Kontrak Penelitian, Nomor: 045A/UN33.8/LL/2017.

\section{DAFTAR PUSTAKA}

Abdi, A. (2014). The Effect of Inquiri-based Learning Method on Student Academic Achievement in Science Course. Universal Journal of Educational Research. 2(1):37.

Andrini, V, S. (2016). The Effectiveness Of Inquiry Learning Method to Enhance Students' Learning Outcome: A Theoritical and Empirical Review. Journal of Education And Practice. 7(3): 38-42.

Bednar, P., Eglin, R., Welch, C. (2007). Contextual Inquiry: A Systemic Support for Student Engagement Through Reflextion. Interdisciplinary Journal of Knowledge and Learning Objects. 7(3): 45-55.

Depdiknas. (2008). Panduan Pengembangan Buku Ajar. Jakarta: Dapertemen Pendidikan Nasional.

Prastowo, A. (2011). Panduan Kreatif Memuat Bahan Ajar Inovatif. Yogyakarta: Diva Press.

Rahmat. (2007). Metode Penelitian Komunikasi.. Bandung: Rosdakarya.

Sanjaya, W. (2009). Strategi Pembelajaran Berorientasi Standar Proses Pendidikan. Jakarta: Kencana.

Sugiyono (2015). Metode Penelitian dan Pengembangan $(R \& D)$. Bandung: Alfabeta.

Widjajanti. (2012). Pengembangan Lemabar Kerja Siswa Berbasis Keterampilan Proses Sains Pada Materi Pencemaran Lingkungan Kelas VIII SMP. Journal Bioedukasi, 5 (2): 23-30. 